\title{
Transformational Change and Regime Shifts in the Circumpolar Arctic
}

\author{
Annika E. Nilsson ${ }^{\star}$ \\ Senior Research Fellow at Stockholm Environment Institute, Stockholm, Sweden and \\ Affiliated Faculty in Environmental Politics at KTH Royal Institute of Technology, \\ Division of History of Science, Technology and Environment, Stockholm, Sweden \\ Timo Koivurova, \\ Research Professor, Director, Arctic Centre/University of Lapland, Rovaniemi, Finland
}

\begin{abstract}
The Arctic is changing rapidly, and there are many indications that the region is in the midst of transformational change. While some of the focus relates to impacts of climate change, rapid economic development and the potential for shifts in political and social structures in the region have also been in the limelight. This article looks at the circumpolar Arctic as a potential case of a regime shift in a large-scale social-ecological system that includes reinforcing feedbacks. A special focus is placed on governance structures, as these play an important role in social negotiations on the relationship between societies and the environment. While climate change is often portrayed as a driver of social change in the Arctic, it does not appear that the ongoing changes in the biophysical features of the Arctic region have rocked current circumpolar governance structures out of kilter. On the contrary, the ongoing climate-related changes, in particular sea ice decline, appear to have reinforced political commitment to existing legal structures. Major past social regime shifts have mainly been related to access to resources and national identity ideology, with political dynamics reinforced at times by military security considerations.
\end{abstract}

Keywords: regime; Arctic; social-ecological system; governance; scale; region

Responsible Editor: Øyvind Ravna, UiT- The Arctic University of Norway, Tromsø, Norway.

Received: August 2016; Accepted: October 2016; Published: November 2016

\section{Introduction}

The Arctic is changing rapidly, and suggestions have been made in both the academic and popular literature that the region is in the midst of transformational change. ${ }^{1}$ Signs of change in the region are sometimes seen as harbingers of social-ecological tipping points due to climate change. ${ }^{2}$ Although most of the attention has related to climate change, the focus has also been on rapid economic development and the

${ }^{\star}$ Correspondence to: Annika E. Nilsson, Stockholm Environment Institute, Box 24218, SE 10451, Stockholm, Sweden. Email: annika.nilsson@sei-international.org 


\section{A.E. Nilsson and T. Koivurova}

potential for shifts in the political and social structures of the region. Examples of the latter are the 'race for resources' rhetoric $^{3}$ and discussions about increasing security tensions. 4

This article looks at the circumpolar Arctic as a potential case of a regime shift of a large-scale social-ecological system (SES) that includes reinforcing feedback mechanisms between the social and ecological features of the Arctic region, leading to a further strengthening of this new regime. Specifically, an analysis of past major transformations of the circumpolar Arctic forms the basis for discussing whether current changes carry the seeds of a lasting reorganization that includes feedback dynamics that make a return to the previous state unlikely. This article is an effort to provide a more nuanced analysis of the social and political dynamics that impact Arctic regime shifts than the previous studies, which have mainly focused on environmental change. Furthermore, it provides a base for discussing the analytical value of political science for notions of regime shifts in SESs.

\subsection{Definitions}

In studies of the resilience of SESs, 'regime shift' refers to substantial and enduring systemic reorganization, where internal dynamics are altered. ${ }^{5}$ The term suggests that reinforcing feedbacks tend to stabilize these new relationships in ways that make it unlikely that the system will shift back to its original state. A 'regime shift' thus entails a new relationship between different components of a system, which is stabilized by some kind of reinforcing feedback. The term often implies that a shift is abrupt and has major implications for economies and societies. ${ }^{6}$ In this article, we also use the term 'transformation'. While the term 'regime shift' refers to new feedback mechanisms that reinforce the organization of the new system, the term 'transformation', as we use it, is a broader descriptor of major change, which may, but does not necessarily, imply a change in feedbacks that affects system dynamics. However, transformation suggests change that goes beyond adapting within the current system. ${ }^{7}$ In the literature, the term 'transformation' is increasingly used to highlight the role of human agency in bringing about change, ${ }^{8}$ often with positive connotations of navigating toward a more desirable future, particularly in relation to sustainability. ${ }^{9}$ However, here we use 'transformation' as a neutral term for fundamental change and do not take a normative stance on whether the change is desirable or not.

\subsection{Arctic regime shifts: A brief review}

Most studies of regime shifts have focused on ecosystems, with numerous documented cases. ${ }^{10}$ There is an increasing focus on linkages between ecological and social dynamics, ${ }^{11}$ with special attention given to the role of management and governance. ${ }^{12}$ In relation to the Arctic, there have been both documented cases and suggestions of ongoing regime shifts. ${ }^{13}$ These include ongoing changes in Arctic Ocean sea ice, ${ }^{14}$ the collapse of Newfoundland fish stocks, ${ }^{15}$ ecosystem changes in the Bering Sea linked to climate patterns, ${ }^{16}$ ongoing shrub expansion on the tundra that foreshadows a transition from tundra to boreal forest, ${ }^{17}$ a potential shift from coniferous to deciduous forest in Alaska's interior, ${ }^{18}$ and the emptying of lakes when permafrost thaws. ${ }^{19}$ The 
Arctic Resilience Report also highlights some potential social regime shifts at the local level, such as changing patterns of livelihoods. ${ }^{20}$ Moreover, Young suggests that there has been a 'state change' in circumpolar political dynamics, pointing to a link between environmental and political changes. ${ }^{21}$

\section{Approach}

To assess whether past and ongoing changes of the circumpolar Arctic can be considered regime shifts of a large-scale SES that affects both environmental and social features and includes reinforcing feedback between them, we critically address the following questions:

- In relation to what features can the circumpolar Arctic be considered a SES? This question relates to defining the scale and the scope of a specific case in a globally interconnected world and to identifying the features that are most relevant to study at the chosen scale.

- What periods of major transformation of Arctic social and ecological features can be identified over the past few centuries? This question addresses whether there have been major shifts in the overarching structures of the region and the extent to which these shifts include an interplay between social and environmental features. The rationale for focusing on historical as well as current developments is that regime shifts are usually easier to identify in hindsight than in the midst of ongoing change.

- Which drivers of change were present during the identified periods of major change and how did they impact major features of the SES? We are particularly interested in the role that ecosystem changes may have played in a transformation of the SES as a whole.

- Can changes during major transformations be linked to reinforcing feedbacks that have contributed to committing the Arctic as a large-scale SES to a different regime compared to the previous one? This question addresses whether identified transformations include changes in feedback mechanisms between the social and biophysical spheres in ways that make it reasonable to talk about a regime shift.

\section{Defining the case}

A major challenge in identifying a social-ecological regime shift is to define the appropriate scale for such an analysis and to decide on case boundaries. While the notion of SESs highlights the links between social and ecological dynamics and places the focus on complex systems dynamics, it has been criticized because the boundaries of any system are arbitrary. ${ }^{22}$ Moreover, cascading effects across scales are highly relevant for understanding regime shifts, ${ }^{23}$ which makes it difficult to define a specific focal scale as more or less appropriate. The relevance of system boundaries thus needs to be established in relation to our analysis. Our choice to focus on the circumpolar 


\section{A.E. Nilsson and T. Koivurova}

Arctic is based on recent scientific and media attention to this area as a region and the debate over how the Arctic as a region should be governed. ${ }^{24}$

While the Arctic is often discussed as one region, it includes a diversity of ecosystems and social settings. Recently, more attention has been devoted to acknowledging the diversity and the global connectedness of the region. ${ }^{25}$ For example, the economic structure of the Arctic is best described as an interlinked multi-scale system of local economies tied to subsistence and/or resource extraction, which in turn is tied to both national economies and global markets. ${ }^{26}$ Politically, the region encompasses the political traditions of eight different countries. It is culturally diverse with a mixture of indigenous peoples and population groups that arrived with colonization and later, as well as a mixture of rural and urban lifestyles. ${ }^{27}$ In spite of this diversity, many social networks are circumpolar in scale, including cooperation among indigenous peoples and among scientists. The most prominent circumpolar social structure is the international cooperation in the Arctic Council, which plays an important role in defining the relationship between different transnational actors, not only member states and indigenous peoples but also the array of states and organizations that are observers to the Council. It has also played a pivotal role in organizing knowledge production in ways that place circumpolar perspectives in focus, ${ }^{28}$ thus contributing to region-building. Exner-Pirot has characterized the Arctic as a regional 'environmental security complex' built around environmental security interdependence that includes a range of both state and non-state actors. ${ }^{29}$

Based on the prominent role that circumpolar political cooperation has played for defining the Arctic as a region, we consider a focus on political structure as a relevant starting point for an analysis of SES features. This focus also provides a unique contribution compared to studies of Arctic regime shifts that take ecosystem changes as their starting point. It offers the advantage of not embedding the assumption that environmental change leads to social change. Moreover, it provides a useful case for assessing the analytical value of notions of regime shifts in SESs in relation to understanding political dynamics. There is no doubt that both climate-related features and social structures are changing in the Arctic. However, responses to climate change might well take place without fundamental changes to the circumpolar social structures, and major changes in social structures might primarily be driven by other trends than climate or environmental change. The attention to political structures also resonates with the call for more attention to issues of power and agency in resilience research. ${ }^{30}$

We specifically highlight governance structures because they play a fundamental role for how social actors relate to each other. Moreover, they provide frameworks within which societies learn, set goals, and make joint decisions that guide relationships between social actors as well as between people and the environment. Specifically, they provide the setting in which societies collectively assign values and negotiate norms about behavior in relation to ecosystems. ${ }^{31}$ Governance structures can also play an important role for organizing knowledge production and, thus, provide a context that affects how societies conceptualize the links and relationships between ecological and social processes. In the Arctic, it is indeed the 
current presence of the Arctic Council as a governance structure that motivates viewing the circumpolar Arctic as a large-scale SES, despite great diversity within this system.

Compared to day-to-day politics, governance structures are often relatively stable over long periods of time, where rules, procedures, and norms provide some predictability about what we can expect from different actors. By upholding the basic values of societies and the rule of law, they create a certain amount of social resilience, for better or for worse. ${ }^{32}$ Legal structures in particular play a major role in defining rights, obligations, and who has the power to act. ${ }^{33}$ But neither laws nor governance structures are permanent, and in turbulent times, they can be changed to create opportunities for new social structures and power relations. When overarching governance structures change, they often alter the rules of the game and create new path dependencies by allowing space for new voices and interests. ${ }^{34}$ The following section discusses Arctic international governance in light of past transformations with a focus on the drivers of change relevant at the time and whether new feedbacks reinforced a new structure of the Arctic as a circumpolar SES. We use this analysis as a background for discussing the resilience of the current circumpolar regime and relevant factors that may function as seeds or drivers of a potential forthcoming regime shift.

\section{Past transformations of the circumpolar Arctic}

\subsection{The increasing role of states: Colonization and war}

A major transformation of social relations in the Arctic occurred when trade and colonization brought non-indigenous actors to the North, connecting these groups with indigenous communities that had previously been largely isolated from international politics and markets. In the more accessible Fennoscandian North, this process accelerated in the 1600s, while remote areas of the Canadian Arctic remained relatively isolated until the mid-1900s. ${ }^{35}$ Colonization was closely linked to nation-building, where northern land areas and societies became linked to national political structures, including rules of taxation, laws, and control over local resources. This can therefore be seen as a fundamental change in political structure at the circumpolar scale, often at the expense of existing indigenous governance structures.

What overarching drivers of change are relevant to explain the observed shift? Colonial expansion came at a time of increasing focus on territorially defined states supported by an international institutional structure that favored norms of state sovereignty. ${ }^{36}$ This served as a backdrop when an increasing interest in the region's resources and an ideological focus on nation-building motivated the economic and political colonization of northern land areas. ${ }^{37} \mathrm{~A}$ major driver is thus found in the realm of political ideals and norms. Arctic ecosystem features played a role in making the region attractive, but ecosystem change can hardly be described as a major driver responsible for these social changes. 


\section{A.E. Nilsson and T. Koivurova}

The new actors arriving in the Arctic had substantial ecological impacts. For example, industrial whaling brought several whale populations to the brink of extinction, ${ }^{38}$ and the fur trade had severe impacts on populations of sea lions and sea otters. ${ }^{39}$ State expansion was later followed by local impacts from mining and related industries ${ }^{40}$ as well as impacts on waterways, forests, and fisheries. ${ }^{41}$ There was thus an interplay between social and environmental changes. Did this interplay also create the potential for feedbacks that would reinforce the new regime? Because the transformation brought on by colonization paved the way for developing infrastructure that made parts of the Arctic more accessible for further integration into larger scale economic systems, it would appear so. Examples include the building of transport and energy infrastructure and the spread of knowledge about the region. ${ }^{42}$ Military operations during World War II added further to the Arctic infrastructure. This new infrastructure, together with state expansion, can be seen as contributing to a reinforcing feedback loop between the social and the biophysical worlds, where physical and legal access has fueled further economic development and a shift toward economic systems more closely linked to the national and international spheres.

With an onus on territorial control as a key feature of the global political system, it also became increasingly important to define rights to marine resources. At the global scale, this issue was accentuated in the 1960s and the 1970s with the development of new technology for offshore oil production, increasing maritime transport and military maritime activities, and a growing concern about pollution and overfishing. The high political stakes created a push to strengthen global ocean governance, eventually resulting in the signing of the UN Convention of the Law of the Sea (UNCLOS) in 1982. This development was not related to the Arctic in particular, but resulted in an expansion of state control over all marine areas, including those in the Arctic. It also set the stage for the current interest in mapping the seabed of the Arctic Ocean.

We argue that the increasing power of states can be seen as a transformation of the global political system that fundamentally changed the conditions for governance of land and marine areas in the Arctic as well. This can be seen as a regime shift in that the legal framework set the stage for feedbacks by providing the rights to resources and, thus, incentives for state actors to engage in economic activities that may have been less attractive if they had been associated with legal uncertainties. This served as a reinforcing feedback together with the new physical infrastructure that made the region more accessible.

\subsection{Region-building}

A second major transformation of the circumpolar Arctic started in the late 1980s, with the early beginnings of regional international cooperation. Michael Gorbachev's Murmansk speech in 1987, in which he proclaimed the Arctic as a zone of peace, is often cited as the seminal event. It was followed by intensive diplomatic activity, which eventually led to the creation of the Arctic Environmental Protection Strategy (AEPS), signed in 1991. Building on the AEPS, the Arctic Council was created in 1996 with the broader goal of sustainable development. ${ }^{43}$ This circumpolar 
political cooperation set the stage for defining the Arctic as a political region. ${ }^{44}$ The transformation of the circumpolar political context over the course of less than a decade was accompanied by increasing recognition of indigenous peoples as legitimate transnational actors. The change toward peaceful development has since facilitated building infrastructures for cooperation, for example, in carrying out scientific assessments and, more recently, in more applied arenas such as search and rescue operations. From its inception as a body that left policy action to other governance mechanisms, the Arctic Council is increasingly taking policy-making initiatives of its own. ${ }^{45}$

What were the drivers of change for this transformation? A key driver of change was the collapse of the Soviet Union and the end of the Cold War. These events completely changed the conditions for international cooperation in a process that has been described as desecuritization. ${ }^{46}$ However, other drivers of change were also at play. An underlying change at the global scale was postwar expansion of a truly global governance system-the United Nations-under whose auspices a new international environmental governance framework was developed in the 1980s and the 1990s. Moreover, peoples with cultural identities that extended beyond national borders began to assert claims about self-determination, giving rise to a transnational indigenous political movement, in which Arctic indigenous peoples played a significant role. ${ }^{47}$ While states have remained the primary actors in transnational politics, the global governance system has also created space for other transnational actors to play a much more prominent role, such as global corporations, non-governmental organizations (NGOs), and the media, as well as horizontal transnational networks, such as cooperation among municipalities and regions across national borders. ${ }^{48}$ These developments in the political landscape have taken place at the same time as globalization has affected everything from economies and geopolitics to cultures and demography. These processes are global processes, and with the fall of the Soviet Union, the Arctic also became integrated into the ongoing transformation of the global society.

The transformation of the international political landscape was partly linked to increasing awareness about the global nature of environmental problems and the need to address this within international frameworks. This awareness figured prominently in the negotiations on the AEPS. In the Arctic context, these negotiations included concerns about high levels of organic contaminants, smelter emissions, and radioactive fallout, where there was a joint need for more knowledge. ${ }^{49}$ Climate scientists were also starting to pay attention to the Arctic and its potential impacts on the global climate system. But the environment was not the only issue on the agenda. Interest in Arctic resources was also at play, in particular offshore oil and gas. Realizing economic opportunities in the Arctic would require political conditions that favored peace and cooperation. Given the history of strategic tensions in the region, the environment was an issue considered to be 'low politics' and therefore a suitable place to start. ${ }^{50}$

What feedbacks have served to reinforce the new collaborative regime? One could argue that scientific assessments conducted under the auspices of political cooperation have played an important role by focusing on the circumpolar scale, which 


\section{A.E. Nilsson and T. Koivurova}

has served to reinforce the notion of the Arctic as a region, as well as put emphasis on common regional interests. The building of new networks has been another important feature of circumpolar cooperation, where the eight Arctic states, and the indigenous peoples recognized by the Arctic Council as Permanent Participants, have been given more legitimacy than other actors in circumpolar affairs. Trust building among these actors followed by more intensive collaborative efforts can be seen as a self-reinforcing mechanism. We argue that the creation of new knowledge generated by these new networks of actors makes it reasonable to talk about a regime shift in system dynamics in contrast to the situation during the Cold War. The fact that such collaboration has also supported activities aimed at reducing pollution and environmental damage is a sign of linkage back to the environmental sphere. ${ }^{51}$

In summary, the fundamental structural change that took place in the circumpolar SES in the 1990s was mainly related to a shift from the conflict regime of the Cold War to one that focused on cooperation, where economic and security interests were important drivers of change along with environmental concerns. We would argue that this constituted a regime shift in the circumpolar SES in that it affected the relationship between key actors and the environment, and served as a trust-building mechanism that reinforced this cooperation.

\section{Is there an ongoing social-ecological regime shift in the Arctic?}

The past decade has featured major changes in the Arctic biophysical system, where global climate change has acted as a driver of ice and snow loss as well as changes in weather patterns and impacts on ecosystems. ${ }^{52}$ To what extent have these biophysical changes also affected fundamental social structures at the circumpolar scale, creating new feedbacks between social and environmental changes? Can the 'state change' suggested by Young ${ }^{53}$ be characterized as a social-ecological regime shift?

There is no doubt that climate change has already had a major societal impact, especially on coastal communities that depend on sea ice as protection against erosion and for subsistence hunting. It is also clear that shrinking sea ice, in particular, has garnered attention to the Arctic from a range of new actors and interests, who increasingly want to be part of Arctic politics. This interest has been met with some reluctance from 'old' Arctic actors and has led to drawn-out deliberations about granting Arctic Council observer status to these newcomers. While several non-Arctic states have now been admitted as observers, the role of these observers has also become more circumscribed. ${ }^{54}$ In addition to this new landscape of actors, Arctic governance structures have been challenged at the rhetorical level, for example, by calls for an Arctic Treaty as well as calls for reform within the context of the Arctic Council. $^{55}$

International political structures will continue to change as new needs, interests, and actors come to the fore. Some changes are likely to be gradual through reforms rather than radical transformation, e.g. the strengthening of the Arctic Council and admittance of new observers. However, the inherent conservatism of any governance structure can also cause a buildup of tensions, where an increasing number of actors 
see a need for more radical change. The political rhetoric following the 2007 sea ice minimum, including discussions about the need for an Arctic Treaty and the so-called Ilulissat Declaration of $2008,{ }^{56}$ has been described as a sign of positioning for such a change. ${ }^{57}$ So far, however, circumpolar international cooperation has not broken down. Rather, commitments to existing international governance structures such as the Arctic Council and UNCLOS have been reaffirmed. Moreover, while environmental crises could play a role in major social change and even the demise of societies, ${ }^{58}$ the threat of environmental damage or crises can also contribute to a recognition of the need to cooperate, as illustrated by the attention paid to environmental issues in the creation of the AEPS. ${ }^{59}$

\subsection{Nested in a global context}

Given that the Arctic is young as a political region and is nested in a political system with strong national structures and a web of global governance structures, any analysis of political changes in the current circumpolar political cooperation also needs to consider political development at other scales. In general, norm development in the Arctic has evolved in line with international developments, exemplified by a growth in global environmental governance that has made discourse on sustainable development an established part of international relations, as reflected in the wider mandate of the Arctic Council compared to the AEPS. ${ }^{60}$

While global governance regimes have provided venues for pushing Arctic priorities on the global arena, such as when Arctic actors pushed for the Stockholm Convention on Persistent Organic Pollutants and the Minamata Convention on Mercury, ${ }^{61}$ the fact that circumpolar governance is nested in a larger governance context has also provided arguments for placing responsibility elsewhere. In particular, the existence of the UN Framework Convention on Climate Change has served as an argument to keep mitigation of climate change off the Arctic Council's agenda, with the exception of work on short-lived climate pollutants such as black carbon (soot). This has also delayed strong engagement in assessing the impacts of climate change. ${ }^{62}$ We argue that this close link between global and regional developments is likely to continue. While recent successes such as the Paris Climate Agreement in 2015 have been achieved, nothing points to imminent changes in the global environmental governance landscape that would push Arctic cooperation in fundamentally new directions.

In another major international development, the Arctic has been both driving a shift in norms and been affected by them, namely, the legal recognition of indigenous peoples' rights. Today, Arctic indigenous peoples are truly transnational actors and constitute their own polities in parallel with nation-states. ${ }^{63}$ Legal developments have also contributed to a recognition of land ownerships rights (although to varying degrees across the Arctic) and a process of political devolution. ${ }^{64}$ However, the major political structures that are directly relevant to the circumpolar scale persist. States remain the major actors and have reasserted their positions through the use of rhetoric, including the issuing of formal Arctic policy statements, ${ }^{65}$ by making international treaties, as well as by carrying out activities that highlight territorial sovereignty as a key principle, such as increased border patrols. Regarding rights in 


\section{A.E. Nilsson and T. Koivurova}

relation to the marine Arctic, all Arctic states and many other Arctic actors adhere to the Law of the Sea, which is largely codified in the UNCLOS, as the central legal regime for solving issues related to governance of marine areas and for solving disputes regarding national maritime jurisdiction.

In summary, it does not appear that substantial ongoing changes in the biophysical features of the Arctic region have rocked current circumpolar governance structures out of kilter, at least not yet. They have not even had a major impact on the relationship between the Arctic and global governance regimes. Rather, the ongoing ecosystem changes, in particular sea ice decline, appear to have reinforced political commitments to these regimes.

\subsection{Drivers of future change}

Do the ongoing changes contain the seeds for a shift to a fundamentally new regime that will also affect power relations and structures for political decision-making? Whether circumpolar regime shifts that affect basic governance structures and norms will occur in the near or more distant future remains speculative. However, given the recent interest in a potential Arctic regime shift, it is nevertheless relevant to briefly discuss major trends that may put pressure on current political structures.

Climate change is certainly one of the trends that will create new demands on governance, both in relation to climate change mitigation and adaptation and in relation to a need to regulate marine activities in an increasingly ice-free Arctic. While many demands relate to national governance, some issues require international coordination and collaboration. Climate change thus provides a seed for potential change, but not necessarily in the form of new governance structures or political relationships. Future developments will more likely hinge on whether powerful actors consider current structures for international collaboration sufficient. A more important seed for potential future change in the governance landscape may therefore lie in shifting power relations among global actors with different interests. An important trend here is the ongoing geopolitical shift of economic and political power toward Asia, with China as a major player.

Another trend is the aforementioned devolution of power to indigenous peoples in the region, including rights to resources, with major implications for the distribution of the economic benefits of industrial development, which may affect the priorities of both states and indigenous peoples. One illustration of this is the current debate in Greenland about the pros and cons of large-scale industrial development as a way to gain economic independence. Shifts in political power and interests are not directly related to ecosystems dynamics, but may well interact with the impacts of climate change. The political climate may also be affected by Russia's political ambitions and activities spilling over to the Arctic to a much greater extent than it has done so far, especially in relation to security concerns.

Other drivers of change that should be considered in assessing the potential for future social-ecological regime shifts at the circumpolar scale are scientific and technological developments. Historic examples include the leaps in climate science that came with computer-based modeling and, later, satellites, which served as a 
foundation for the recognition that the Arctic plays a fundamental role for the global climate as a potential accelerator of climate change. Technological developments fundamental to current interests in the Arctic also include the capacity of large-scale industrial operations to work offshore. The rapid development of fracking may yet again change the rules of the game. Energy-related technological or political breakthroughs related to the use of fossil fuels may also be important for national interests and, thus potentially, also for circumpolar international relations. Falling energy prices are already affecting the potential profitability of offshore Arctic hydrocarbons and the willingness to invest in these ventures, with potential feedback on perceived national interests in developing Arctic hydrocarbon resources, which in turn links to geopolitical and security concerns.

The difficulty is not in listing drivers of change that may affect political structure and governance at the circumpolar scale. The challenge lies in assessing the impact of these drivers, how they relate to each other, and whether they have the potential to create new self-reinforcing feedbacks between environmental and social processes in ways that drive a social-ecological regime shift at the circumpolar scale. As judged by history, the impetus for change may not necessarily originate from within the region. It can come from developments in global politics, from changes in perceived interests within Arctic states, from scientific and technological breakthroughs, as well as from an interaction between global, regional, and national dynamics. It points to the importance of analyzing the circumpolar Arctic system as linked to both global and national processes and may even challenge the specific circumpolar scalar focus. Moreover, the two historical transformations discussed in this article point to the importance of paying as much attention to political drivers of change, including perceived interests and power relations, as to the biophysical impacts of climate change.

\section{Conclusions and discussion}

Climate change has already begun to fundamentally alter Arctic ecosystems on a circumpolar scale, with further consequences expected both locally and globally. While environmental change, with climate change in particular, is often portrayed as a driver of fundamental social change in the Arctic, there is no indication that climate or ecosystem changes have, as yet, played a role in fundamentally shifting relations between transnational actors at the circumpolar scale. Regime shifts at the circumpolar scale that have occurred in the past have mainly been related to a quest for resources and national identity ideology, reinforced at times by military security considerations.

Knowledge and awareness about environmental change can serve as a potential feedback loop between social and biophysical systems. It played a role in the transformation from the conflict-ridden relations of the Cold War to the current transnational cooperative environment. However, knowledge about ongoing climaterelated ecosystem change has not, as yet, fundamentally altered the international political structures that developed in the 1990s. 


\section{A.E. Nilsson and T. Koivurova}

Is there a need for a transformational change of governance structures in response to ongoing social and environmental changes in the Arctic? Strong arguments have been made that social-ecological resilience is now eroding in the Arctic at such a pace that transformation may become inevitable or is indeed needed in order to safeguard human welfare. ${ }^{66}$ Chapin et al. specifically delineate a new stewardship ethic for conservation efforts. ${ }^{67}$ However, such a change can take place within existing political structures. For example, the 2008 Ilulissat Declaration highlighted that coastal states, because of the Law of the Sea, have a stewardship role to protect the Arctic Ocean as a unique ecosystem. ${ }^{68}$

Earlier calls for reform of the Arctic Council and for an Arctic Treaty can also be seen as signs that there is a perceived need for change. Actions, ranging from increasing military activity to a scientific and commercial presence in the region, and rhetoric featured in media are other signs that the current situation is more fluid than what it was a decade ago. Such discussions and actions are likely to continue, and their dynamics provide an important empirical foundation for further studies of actual or potential social-ecological regime shifts at the circumpolar scale. However, such studies will also require further development of the theoretical foundation for understanding the social dimensions of regime shifts and their link to environmental change. In addition to previously mentioned calls for more attention to agency and power, the historical importance of perceived interests among various groups of actors, and identity politics as drivers of change in the Arctic, points to a need for studying visions of the future among different actors, ${ }^{69}$ and how various narratives can serve as a form of 'soft' power that interacts with physical and political regimes in shaping change.

This article uses the notion of regime shifts in SESs as an analytical lens for highlighting the dynamics of fundamental systems change that relate to political structures and power. The analytical approach has its roots in ecology and has been criticized for lack of attention to agency and power. Our review of Arctic change shows that this limitation can, at least partly, be addressed by placing more analytical focus on political processes and governance structures. An advantage of focusing on SESs is that it directs analytical attention to interactions between social and biophysical processes and to potential feedbacks between them, which is often lacking in social science studies. However, analyses of regime shifts in SESs require carefully argued definitions of case boundaries and a thorough discussion of connectivity across scales. The case of the circumpolar Arctic also shows that further work is needed to determine if and when large international regions are useful units of analysis for understanding social-ecological regime shifts. Moreover, the empirical material cautions against making assumptions that environmental change will be the most important factor for political and structural transformations.

\section{ACKNOWLEDGEMENTS}

The work discussed in this article was carried out in the context of the Arctic Resilience Assessment, led by Stockholm Environment Institute and the Stockholm 
Resilience Centre, and was financially supported by the Swedish Environmental Protection Agency. It was also supported by the Formas-funded project 'Arctic Governance and the Question of Fit in a Globalized World.' We also acknowledge the inspiration provided by the Arctic Resilience Assessment Part 3 Team.

\section{NOTES}

1. ACIA, Arctic Climate Impact Assessment 2005. (Cambridge: Cambridge University Press, 2005); AMAP, Snow, Water, Ice and Permafrost in the Arctic (SWIPA): Climate Change and the Cryosphere. (Oslo, Norway: Arctic Monitoring and Assessment Programme, 2011); Robert W. Corell et al., in Tessa Goverse/UNEP, ed., 'View from the Top: Searching for Responses to a Rapidly Changing Arctic', in UNEP 2013 Yearbook (Nairobi, Kenya: United Nations Environment Programme, 2013), 19-35; and Joan Nymand Larsen and Gail Fondahl, eds., Arctic Human Development Report. Regional Processes and Global Challenges, TemaNord, 2014:567 (Copenhagen, Denmark: Nordic Council of Ministers, 2014).

2. e.g. ACIA, Impacts of a Warming Arctic: Arctic Climate Impact Assessment Cambridge: Cambridge University Press, 2004; Paul Wassmann and Timothy M. Lenton, 'Arctic Tipping Points in an Earth System Perspective', AMBIO 41 (2012): 1-9, doi: http://dx.doi. org/10.1007/s13280-011-0230-9; and Sarah Cornell et al., 'Thresholds in the Arctic', in Arctic Resilience Interim Report 2013, ed. Arctic Council (Stockholm, Sweden: Stockholm Environment Institute and Stockholm Resilience Centre, 2013), 37-69.

3. Timo Koivurova, 'The Dialectic of Understanding Progress in Arctic Governance', Michigan State International Law Review 22 (2013): 1-21, http://papers.ssrn.com/sol3/papers.cfm? abstract_2373863.

4. Robert Huebert et al., Climate Change $\mathbb{E}$ International Security: The Arctic as a Bellwether (Arlington, VA: Center for Climate and Energy Solutions, 2012), http://www.c2es.org/ publications/climate-change-international-arctic-security; and James Kraska, ed., Arctic Security in An Age of Climate Change (Cambridge; Cambridge University Press, 2011).

5. Marten Scheffer and Stephen R. Carpenter, 'Catastrophic Regime Shifts in Ecosystems: Linking Theory to Observation', Trends in Ecology E Evolution 18 (2003): 648-56, doi: http://dx.doi.org/10.1016/j.tree.2003.09.002; and Carl Folke et al., 'Regime Shifts, Resilience, and Biodiversity in Ecosystem Management', Annual Review of Ecology, Evolution, and Systematics 35 (2004): 557-81.

6. Reinette Biggs, Stephen R. Carpenter, and William A. Brock, 'Turning Back from the Brink: Detecting an Impending Regime Shift in Time to Avert It', Proceedings of the National Academy of Sciences 106 (2009): 826-31, doi: http://dx.doi.org/10.1073/pnas.0811729106.

7. Adaptation refers to the process by which a social-ecological system 'copes with, manages and adjusts to change' (Barry Smit and Johanna Wandel, 'Adaptation, Adaptive Capacity and Vulnerability', Global Environmental Change 16 (2006): 282), without necessarily challenging the current system logic.

8. Ross Gillard, 'Questioning the Diffusion of Resilience Discourses in Pursuit of Transformational Change', Global Environmental Politics 16 (2016): 13-20, doi: http://dx.doi.org/10. 1162/GLEP_a_00334.

9. Per Olsson, Victor Galaz, and Wiebren J. Boonstra, 'Sustainability Transformations: A Resilience Perspective', Ecology and Society 19, no. 4 (2014): 1, doi: http://dx.doi.org/10. 5751/ES-06799-190401.

10. Marten Scheffer et al., 'Catastrophic Shifts in Ecosystems', Nature 413 (2001): 493-502; Marten Scheffer, Critical Transitions in Nature and Society, Princeton Studies in Complexity (Princeton, NJ: Princeton University Press, 2009); and Juan-Carlos Rocha et al., 'Marine Regime Shifts: Drivers and Impacts on Ecosystems Services', Philosophical Transactions of the 
Royal Society of London B: Biological Sciences 370 (2015): 20130273, doi: http://dx.doi.org/ 10.1098/rstb.2013.0273.

11. Fikret Berkes and Carl Folke, eds., Linking Social and Ecological Systems: Management Practices and Social Mechanisms for Building Resilience (Cambridge: Cambridge University Press, 2002); Fikret Berkes, Johan Colding and Carl Folke, eds., Navigating Social-Ecological Systems (Cambridge: Cambridge University Press, 2003); and Ann P. Kinzig et al., 'Resilience and Regime Shifts: Assessing Cascading Effects', Ecology and Society 11, no. 1 (2006): 20, http://researchrepository.murdoch.edu.au/541/

12. e.g. Anne-Sophie Crépin et al., 'Regime Shifts and Management', Ecological Economics, The Economics of Degrowth, 84 (December 2012): 15-22, doi: http://dx.doi.org/10.1016/j. ecolecon.2012.09.003; and Oran R. Young, 'Arctic Tipping Points: Governance in Turbulent Times', AMBIO: A fournal of the Human Environment 41 (2012): 75-84, doi: http://dx.doi.org/10.1007/s13280-011-0227-4.

13. Sarah Cornell, et al. 'Thresholds in the Arctic', in Arctic Resilience Interim Report 2013, ed. Arctic Council (Stockholm, Sweden: Stockholm Environment Institute and Stockholm Resilience Center, 2013), 37-69; and Gary Peterson and Juan Carlos Rocha, 'Arctic regime shifts and resilience', Chap. 3 in Arctic Resilience Report (Stockholm: Stockholm Environment Institute and Stockholm Resilience Center, forthcoming November 2016), 64-95.

14. Valerie N. Livina and Timothy M. Lenton, 'A Recent Tipping Point in the Arctic Sea-Ice Cover: Abrupt and Persistent Increase in the Seasonal Cycle since 2007', arXiv:1204.5445 (April 24, 2012)[Physics], http://arxiv.org/abs/1204.5445; and Peter Wadhams, 'Arctic Ice Cover, Ice Thickness and Tipping Points', AMBIO 41 (2012): 23-33, doi: http://dx.doi.org/ 10.1007/s13280-011-0222-9.

15. Brad de Young et al., 'Regime Shifts in Marine Ecosystems: Detection, Prediction and Management', Trends in Ecology E Evolution 23, no. 7 (2008): 402-9, doi: http://dx.doi.org/ 10.1016/j.tree.2008.03.008.

16. Jacqueline M. Grebmeier et al., 'A Major Ecosystem Shift in the Northern Bering Sea', Science 311 (2006): 1461-64, doi: http://dx.doi.org/10.1126/science.1121365.

17. Ken Tape, Matthew Sturm, and Charles Racine, 'The Evidence for Shrub Expansion in Northern Alaska and the Pan-Arctic', Global Change Biology 124 (2006): 686-702, doi: http://dx.doi.org/10.1111/j.1365-2486.2006.01128.x; Daan Blok et al., 'What Are the Main Climate Drivers for Shrub Growth in Northeastern Siberian Tundra?', Biogeosciences Discussions 8(2011): 1169-79, doi: http://dx.doi.org/10.5194/bgd-8-771-2011; Isla $\mathrm{H}$. Myers-Smith et al., 'Shrub Expansion in Tundra Ecosystems: Dynamics, Impacts and Research Priorities', Environmental Research Letters 6 (2011): 45509; and Terry V. Callaghan et al., 'Ecosystem Change and Stability over Multiple Decades in the Swedish Subarctic: Complex Processes and Multiple Drivers', Philosophical Transactions of the Royal Society B 368 (2013): 20120488, doi: http://dx.doi.org/10.1098/rstb.2012.0488.

18. Daniel H. Mann et al., 'Is Alaska's Boreal Forest Now Crossing a Major Ecological Threshold?', Arctic, Antarctic, and Alpine Research 44 (2012): 319-31.

19. Callaghan et al., 'Ecosystem Change and Stability over Multiple Decades in the Swedish Subarctic'.

20. Miriam Huitric, Garry Peterson and Juan Carlos Rocha, 'What factor build or erode resilience in the Arctic?', Chap. 4 in Arctic Resilience Report, ed. Arctic Council (Stockholm: Stockholm Environment Institute and Stockholm Resilience Centre, forthcoming November 2016): 96-125.

21. Oran R. Young, 'Whither the Arctic 2009? Further Developments', Polar Record 45 (2009): 179, doi: http://dx.doi.org/10.1017/S0032247408008061.

22. Andreas Duit, 'Resilience Thinking: Lessons for Public Administration', Public Administration 94 (2015): 364-80, doi: http://dx.doi.org/10.1111/padm.12182. 
23. Ann P. Kinzig et al., 'Resilience and Regime Shifts: Assessing Cascading Effects', Ecology and Society 11, no. 1 (2006): 20, http://researchrepository.murdoch.edu.au/541/; and Andreas Duit and Victor Galaz, 'Governance and Complexity-Emerging Issues for Governance Theory', Governance 21 (2008): 311-35, doi: http://dx.doi.org/10.1111/j. 1468-0491.2008.00402.x.

24. Paul Arthur Berkman and Oran R. Young, 'Science and Government. Governance and Environmental Change in the Arctic Ocean', Science 324, no. 5925 (2009): 339-40, doi: http://dx.doi.org/10.1126/science.1173200; Oran R. Young, 'If an Arctic Ocean Treaty Is Not the Solution, What Is the Alternative?', Polar Record 47 (2011): 327-34, doi: http:// dx.doi.org/10.1017/S0032247410000677; Koivurova, 'The Dialectic of Understanding Progress'; and Timo Koivurova, 'Gaps in International Regulatory Frameworks for the Arctic Ocean', in Environmental Security in the Arctic Ocean, ed. Paul Arthur Berkman and Alexander N. Vylegzhanin, NATO Science for Peace and Security Series C: Environmental Security (Dordrecht, The Netherlands: Springer, 2013), 139-55.

25. Larsen and Fondahl, Arctic Human Development Report.

26. Lee Huskey, Ilmo Mäenpää, and Alexander Pelyasov, 'Economic Systems', in Arctic Human Development Report. Regional Processes and Global Challenges, ed. Joan Nymand Larsen and Gail Fondahl, TemaNord, 2014: 567 (Copenhagen, Denmark: Nordic Council of Ministers, 2014), 151-82.

27. Timothy Heleniak, 'Arctic Populations and Migrations', in Arctic Human Development Report. Regional Processes and Global Challenges, ed. Joan Nymand Larsen and Gail Fondahl, TemaNord, 2014: 567 (Copenhagen, Denmark: Nordic Council of Ministers, 2014), 53-104.

28. Olav Schram Stokke, 'International Institutions and Arctic Governance', in International Cooperation and Arctic Governance: Regime Effectiveness and Northern Region Building, ed. Olav Schram Stokke and Geir Hønneland (London: Routledge, 2006), 330-54; Paula Kankaanpää and Oran R. Young, 'The Effectiveness of the Arctic Council', Polar Research 31 (2012): 17176, doi: http://dx.doi.org/10.3402/polar.v31i0.17176; and Annika E. Nilsson, 'Knowing the Arctic: The Arctic Council as a Cognitive Forerunner', Chap. 7 in The Arctic Council: Its Place in the Future of Arctic Governance, ed. Thomas S. Axworthy, Timo Koivurova, and Kamrul Hossain (Toronto, Canada: Munk-Gordon Arctic Security Program, 2012): 190-220.

29. Heather Exner-Pirot, 'What Is the Arctic a Case of? The Arctic as a Regional Environmental Security Complex and the Implications for Policy', The Polar fournal 3 (2013): 120-35, doi: http://dx.doi.org/10.1080/2154896X.2013.766006.

30. Duit, 'Resilience Thinking'; and Maureen Biermann et al., 'Approaching a Critical Turn? A Content Analysis of the Politics of Resilience in Key Bodies of Resilience Literature', Resilience 4 (2016): 58-78; doi: http://dx.doi.org/10.1080/21693293.2015.1094170.

31. Martin Sommerkorn and Annika E Nilsson, 'Governance of Arctic Ecosystem Services', in The Economics of Biodiversity and Ecosystem Services TEEB Scoping Study for the Arctic, ed. CAFF (Akureyri, Iceland: Conservation of Arctic Flora and Fauna, 2015), 51-76.

32. Cornell et al., 'Thresholds in the Arctic'.

33. Jonas Ebbesson, 'The Rule of Law in Governance of Complex Socio-Ecological Changes', Global Environmental Change, Governance, Complexity and Resilience, 20 (2010): 414-22, doi: http://dx.doi.org/10.1016/j.gloenvcha.2009.10.009.

34. Dag Avango, Annika E. Nilsson, and Peder Roberts, 'Arctic Futures: Voices, Resources and Governance', Polar fournal 13 (2013): 431-46; doi: http://dx.doi.org/10.1080/2154896X. 2013.790197.

35. AHDR, Arctic Human Development Report (Akureyri: Stefansson Arctic Institute, 2004); and Lars Elenius, ed., The Barents Region: A Transnational History of Subarctic Northern Europe. (Oslo, Norway: Pax, 2015). 


\section{A.E. Nilsson and T. Koivurova}

36. Jessica M. Shadian, The Politics of Arctic Sovereignty. Oil, Ice and Inuit Governance (London and New York: Routledge, 2014).

37. Michael T. Bravo and Sverker Sörlin, Narrating the Arctic. A Cultural History of Nordic Scientific Practices (Canton, MA: Science History Publications, 2002); Charles Emmerson, The Future History of the Arctic (London: Bodley Head, 2010); Shadian, The Politics of Arctic Sovereignty; and Elenius, The Barents Region.

38. Donald G. Reid, Dominique Berteaux, and Kristin L. Laidre, 'Mammals', in Arctic Biodiversity Assessment, ed. CAFF (Akureyri, Iceland: CAFF International Secretariat, 2013), 79-141.

39. F. Stuart Chapin III et al., 'Ecosystem Stewardship: A Resilience Framework for Arctic Conservation', Global Environmental Change 34 (2015): 207-17, doi: http://dx.doi.org/10. 1016/j.gloenvcha.2015.07.003.

40. see e.g. AMAP, Arctic Pollution Issues: A State of the Arctic Environment Report (Oslo, Norway: Arctic Monitoring and Assessment Programme, 1997).

41. Elenius, The Barents Region.

42. Bravo and Sörlin, Narrating the Arctic; and Urban Wråkberg, 'Science and Industry in Northern Russia from a Nordic Perspective', in Science, Geopolitics and Culture in the Polar Region: Norden beyond Borders, ed. Sverker Sörlin, The Nordic Experience 2 (Farnham, Surrey: Ashgate, 2013): 195-223.

43. Arctic Council, 'Declaration on the Establishment of the Arctic Council. 19 September 1996. Ottawa, Canada', 1996, https://oaarchive.arctic-council.org/handle/11374/85.

44. Oran R. Young, Creating Regimes: Arctic Accords and International Governance (Ithaca, NY: Cornell University Press, 1998); Monica Tennberg, Arctic Environmental Cooperation: A Study in Governmentability (Hants and Burlington: Ashgate Publishing Company, 2000); and Carina Keskitalo, Negotiating the Arctic. The Construction of an International Region (London: Routhledge, 2004).

45. Kankaanpää and Young, 'The Effectiveness'; and Douglas C. Nord, 'Creating a Framework for Consensus Building and Governance: An Appraisal of the Swedish Arctic Council Chairmanship and the Kiruna Ministerial Meeting', in Arctic Yearbook 2013, ed. Lassi Heininen (Akureyri, Iceland: Norther Research Forum, 2013): 249-263, http://www. arcticyearbook.com/images/Articles_2013/NORD_AY13_FINAL.pdf

46. Kristian Åtland, 'Mikhail Gorbachev, the Murmansk Initiative, and the Desecuritization of Interstate Relations in the Arctic', Cooperation and Conflict 43 (2008): 289-311, doi: http:// dx.doi.org/10.1177/0010836708092838.

47. Elenius, The Barents Region; Exner-Pirot, 'What Is the Arctic a Case Of?'

48. Frank Biermann and Philipp Pattberg, eds., Global Environmental Governance Reconsidered (Cambridge, MA: MIT Press, 2012).

49. Young, Creating Regimes.

50. Ibid.; and Annika E. Nilsson, 'The Arctic Environment - From Low to High Politics', in Arctic Yearbook 2012 (Akureyri: Northern Research Forum, 2012): 180-194, http://www. arcticyearbook.com/images/Articles_2012/Nilsson.pdf.

51. Annika E. Nilsson and Chanda L. Meek. 'Learning to live with change', Chap. 6 in Arctic Resilience Report (Stockholm: Stockholm Environment Institute and Stockholm Resilience Center, forthcoming November 2016).

52. ACIA, Arctic Climate Impact Assessment; AMAP, Snow, Water, Ice and Permafrost; Corell et al., 'View from the Top'; Arctic Council, Arctic Resilience Interim Report 2013 (Stockholm, Sweden: Stockholm Environment Institute and Stockholm Resilience Centre, 2013); and Joan Nymand Larsen et al., 'Polar Regions', in Climate Change 2014: Impacts, Adaptation, and Vulnerability. Part B: Regional Aspects. Contribution of Working Group II to the Fifth Assessment Report of the Intergovernmental Panel on Climate Change, ed. Vicente R. Barros et al. (Cambridge, U.K. and New York: Cambridge University Press, 2014): 1567-1612 
53. Young, 'Whither the Arctic 2009?'

54. Arctic Council, 'Arctic Council Observer Manual for Subsidiary Bodies', 2013, https:// oaarchive.arctic-council.org/handle/11374/939 (accessed August 26, 2016).

55. Timo Koivurova, 'Alternatives for an Arctic Treaty - Evaluation and a New Proposal', Review of European Community \& International Environmental Law 17 (2008): 14-26, doi: http://dx.doi.org/10.1111/j.1467-9388.2008.00580.x; Timo Koivurova and E.J. Molenaar, 'International Governance and Regulation of the Marine Arctic. Overview and Gap Analysis', 2009; Berkman and Young, 'Science and Government'; Paul Arthur Berkman, Environmental Security in the Arctic Ocean: Promoting Co-Operation and Preventing Conflict (London and New York: Routledge, 2010); Arctic Governance Project, 'Arctic Governance in an Era of Transformative Change: Critical Questions, Governance Principles, Ways Forward. Report of the Arctic Governance Project' (Arctic Governance Project, April 14, 2010), arcticgovernance.org; and Koivurova, 'The Dialectic of Understanding Progress'.

56. Arctic Ocean Conference, 'The Ilulissat Declaration'. Arctic Ocean Conference, Ilulissat, Greenland, May 27-28, 2008, http://www.oceanlaw.org/downloads/arctic/Ilulissat_Declaration. pdf. (accessed August 26, 2016).

57. Oran Young, 'Arctic Tipping Points: Governance in Turbulent Times', AMBIO: A fournal of the Human Environment 41 (2012): 75-84, doi: http://dx.doi.org/10.1007/s13280-0110227-4.

58. Jared Diamond, Collapse: How Societies Choose to Fail or Survive (London: Penguin, 2006).

59. Young, Creating Regimes; and Tennberg, Arctic Environmental Cooperation.

60. Even if the shift itself and the further development of this priority have been accompanied with conflicting interests, see Young and Kankaanpää in Bruce C. Forbes and Gary P. Kofinas, 'Resource Governance', in Arctic Human Development Report. Regional Processes and Global Challenges, ed. Joan Nymand Larsen and Gail Fondahl, TemaNord, 2014: 567 (Copenhagen, Denmark: Nordic Council of Ministers, 2014), 255-98.

61. David L. Downie and Terry Fenge, eds., Northern Lights Against POPs (Montreal \& Kingston: McGill-Queen's University Press, 2003); Nilsson, 'Knowing the Arctic'; and Timo Koivurova, Paula Kankaanpää, and Adam Stępien, 'Innovative Environmental Protection: Lessons from the Arctic', fournal of Environmental Law 27(2015): 285-311, doi: http://dx.doi.org/10.1093/jel/equ037.

62. Koivurova, Kankaanpää, and Stepien, 'Innovative Environmental Protection'; and Annika E. Nilsson, 'A Changing Arctic Climate: Science and Policy in the Arctic Climate Impact Assessment', in Koivurova, Timo, E. Carina H. Keskitalo and Nigel Bankes (eds.),Climate Governance in the Arctic (Berlin: Springer, 2009), 77-95.

63. Shadian, The Politics of Arctic Sovereignty.

64. Nigel Bankes and Timo Koivurova, 'Legal Systems', in Arctic Human Development Report. Regional Processes and Global Challenges, ed. Joan Nymand Larsen and Gail Fondahl, TemaNord, 2014: 567 (Copenhagen, Denmark: Nordic Council of Ministers, 2014), 221-52.

65. Alyson Bailes JK and Lassi Heininen, Strategy Papers on the Arctic or High North: A Comparative Analysis (Reykjavik, Iceland: Institute of International Affairs. Centre for Small State Studies, 2012).

66. Arctic Council, Arctic Resilience Interim Report 2013; and Chapin et al., 'Ecosystem Stewardship'.

67. Chapin et al., 'Ecosystem Stewardship'.

68. Arctic Ocean Conference, 'The Ilulissat Declaration'

69. Mark Nuttall, 'Tipping Points and the Human World: Living with Change and Thinking about the Future', AMBIO 41 (2012): 96-105, doi: http://dx.doi.org/10.1007/s13280-0110228-3. 